\title{
4 \\ The Rocky Road to Revolution
}

In October 1934, Chiang Kai-shek's encirclement campaign forced the Communist leadership to abandon the Central Soviet in Jiangxi and set forth on the Long March. Over the course of its retreat from central China, the Red Army suffered enormous casualties, losing fully 90 percent of its numbers. Through much of 1935 , the main force of the Red Army fought for its life while wandering about western China with little clear direction. In June, Mao Zedong's troops joined those of Zhang Guotao in Sichuan, but soon these two founding members of the CCP parted ways and Mao continued north into Gansu. Despite the slogan and subsequently constructed narrative of going north to fight Japan (beishang kang-Ri 北上抗日), Mao in fact hoped to find refuge along the border of the Soviet Union. These plans changed after Mao entered southern Gansu and learned from a Guomindang newspaper that there was a substantial Communist soviet in northern Shaanxi. ${ }^{1}$ Exactly what Mao read is not known, but most likely it was a frontpage Dagongbao report of an alarmist speech by Shanxi governor Yan Xishan, under the attention-grabbing headline "Shaanbei Red Bandits Growing Peril: 23 Shaanbei Counties Almost All Red." The speech claimed that all northern Shaanxi counties were Red to a degree and eight were totally under Communist control. ${ }^{2}$ To the surprise of the weary soldiers on the long retreat from Jiangxi, they had discovered a vital soviet base in the hills of northern Shaanxi. That was enough to alter the direction of what would soon be called the Long March, and ultimately to change the course of Chinese history.

The survival of the Shaanbei soviet was no mean achievement. By 1935, the other Chinese soviets had all been crushed by Chiang Kai-shek's extermination campaigns. In a formula that became standard in the 1940s, the party lost 100 percent of its following in the "White" Nationalist Party areas and 90 percent in the Red bases. ${ }^{3}$ Shaanbei alone survived, and provided an indispensable refuge at the end of Mao's tortuous retreat from Jiangxi. Soon Mao was joined by He Long, from western Hunan, and the remnants of Zhang Guotao's army. From 1935 to 1948, the 
party Center was based in Shaanbei; during the War of Resistance against Japan, the Communists organized the Shaan-Gan-Ning Border Region with its capital in Yan'an. In the end, Shaan-Gan-Ning claimed control of thirty-one counties, of which eight were newly created. ${ }^{4}$ The area eventually became a stable Communist base, and Yan'an emerged as a Mecca for progressive youths seeking an alternative to Guomindang rule. In Yan'an, Mao and his colleagues developed the strategies that would lead the party to nationwide victory in 1949.

In most histories of the Communist revolution, the caves of Shaanbei provided a safe refuge for the Red Army to recuperate from the trials of the Long March and for Mao and his colleagues to plot their future course. Rarely mentioned is the fact that not long before Mao's army left Jiangxi on its wandering retreat to the north, the revolutionary movement in Shaanxi was in shambles. At the end of 1933, Liu Zhidan had just returned from the disastrous expedition south of the Wei River. He survived with only a few comrades, and fewer than a hundred soldiers would eventually straggle back to Shaanbei. While Liu was campaigning in Weinan, the Communist rear guard had been driven from its base in Zhaojin. In Liu's native county, Bao'an, the fragile party organization had been destroyed, and Communist activity came to a halt. ${ }^{5}$ Liu's small guerrilla detachment faced a severe winter in the poor and sparsely populated Nanliang hills on the Shaanxi-Gansu border.

At roughly the same time, Xie Zichang, leader of the Communist movement east of Yan'an, returned to his home in Anding. There the local guerrillas had recently suffered such losses that they decided to bury their weapons, hoping to live to fight another day. When Xie chastised them for defeatism, he was able to organize a force of only ten men. Everywhere in Shaanbei, the revolution was at a low point in the winter of 1933-34. Meanwhile, in Xi'an and the Wei River valley, the years of famine were over, and Shaanxi was at last escaping its reputation for lagging development and social isolation. By 1931 a motor road from Xian and the slowly advancing railway from the east had reduced the trip to Beijing from three weeks to three days. Irrigation works helped spur cotton production, and commercial agriculture was no longer confined to the opium poppy. Soon Xian would have electricity, running water, and the first modern factories. ${ }^{6}$ With economic progress in the Nationalist areas and the Communist Party decimated, how in the space of a year and a half did the revolutionary base expand to become a plausible refuge at the end of Mao's Long March? As we begin this narrative, it is important to remember that even before the disastrous defeats of 1933, most Shaanbei guerrilla actions were small-scale raids on isolated militia outposts or vulnerable landlords. Never before had they been able to take a fortified town, much less a county seat. Only a new set of contingencies can explain the dramatic victories of 1935 .

\section{NANLIANG AND THE TWENTY-SIXTH RED ARMY}

While Liu Zhidan led his forces on the ill-fated expedition south of the Wei River, the rear guard in the Zhaojin base was joined by a well-armed force under Wang 
Taiji. Wang had fought alongside Liu Zhidan in the Wei-Hua Uprising of 1928, then joined Yang Hucheng's army, where in 1933 he commanded a horseless "cavalry" battalion in Yao-xian. In July, Wang led 1,300 men in a mutiny, but after a confused uprising and several military setbacks, only 100 committed soldiers followed Wang to join the Communists at Zhaojin. He brought with him a hundred unassembled machine guns and several mortars, weapons that greatly increased the firepower of the guerrilla force. ${ }^{7}$ The machine guns were an especially prized acquisition; the guerrillas had long envied this powerful weapon of their opponents. ${ }^{8}$ Wang Taiji was made commander of the guerrilla forces and proved an able military tactician, leading the now better armed guerrillas to several military victories.

The Twenty-Sixth Army's new political commissar was Gao Gang, who had barely escaped the Xi'an arrest of the provincial leadership in July. With military command in the hands of a defector from the Nationalist army, Gao provided a commissar with considerable experience in the party and a potential link to higher party organs. On the other hand, just a year earlier, Gao had condemned the guerrillas as "bandits" and "opium-dealing hooligans" and urged a purge of the leadership to force them to follow the provincial committee's Bolshevik line. ${ }^{9}$ In the summer of 1933, Gao quickly changed his tune, in a reversal that would permanently link his fate to the Shaan-Gan revolutionary movement. Gao's motivations are lost in the mists of time, but his entire controversial life suggests a shrewd and ambitious Communist who quickly grasped the best way to advance the revolutionary cause and his own career. Having barely escaped arrest in Xi'an, Gao was a marked man in the cities. A Shaanbei native, he now hitched his fate to the guerrilla movement, beginning his ascent in the Shaanxi revolutionary movement as an ally of Liu Zhidan rather than an appointee of Xi'an. ${ }^{10}$ In August, he beat back efforts of the "rightist" Sanyuan Communists to disperse the guerrillas and wait for another day. Instead the army decided to expand into the hills to the north, and after Zhaojin was lost in October, Gao and Wang led their army north to a new base in Nanliang. ${ }^{11}$

In Nanliang, Liu Zhidan, after recovering from the trials of the Weinan fiasco, rejoined the guerrillas. The Bolsheviks in the provincial committee had long accused Liu of ignoring the cities and pushed him to concentrate attacks near the urban areas of the Wei River valley. Now he was free to chart his own revolutionary strategy. The new base in Nanliang was about 150 kilometers north of Zhaojin, separated from the center of provincial power by a low range of mountains, thick forests, and a lack of significant roads. The town of Nanliang lay on the Gansu side of the border, while the guerrilla strongholds were nestled in the hills south of neighboring Bao'an in Shaanxi. This was an ungoverned and ungovernable border region far from any concentration of state power. ${ }^{12}$ Most of the residents were recent migrants from counties in northeastern Shaanxi, fleeing famine in their home districts and repopulating an area still recovering from the Muslim Rebellion. Land was held by large landlords, many organized in corporate lineages unusual in this area. This provided a reasonably favorable environment for 
class-based revolutionary appeals. ${ }^{13}$ Of more immediate advantage to the guerrillas, however, was the local power of the Society of Brothers. Liu Zhidan was a member of this society, and it supplied intelligence for his guerrillas; Brothers in the militia provided ammunition; and their families harbored guerrilla casualties as they recovered from wounds suffered in combat. ${ }^{14}$

This isolated border area had long been plagued by bandits, and most landlords had retreated to walled towns or mountain fortresses, leaving the guerrillas space to operate in the hills and small hamlets. The Communists were regarded as a new generation of tramps (liulanghan 流浪汉), not so different from the ever-present bandits. Their struggle was not, however, on behalf of tenants opposing landlords. As always, it was oppressive taxes that aroused popular opposition, and tax collectors were the prime victims of guerrilla assassinations. Liu's forces avoided any complex Marxist propaganda. Their message was simple: they were attacking the rich to aid the poor. This justified the tactic that fed their army: collecting ransom by kidnapping members of wealthy families. ${ }^{15}$ Their efforts to reform local customs were minimal and easily deferred. Opium use was widespread in the area, and smokers made it clear that if the poppy was banned, they would support the Communists' enemies. In neighboring Shanxi, Yan Xishan had launched a vigorous antiopium campaign, and one result was that many opium smugglers and their guards were losing money and joining the Communist guerrillas. Responding to popular pressure, the guerrillas postponed any opium ban for two years. ${ }^{16}$

In the guerrilla army, Wang Taiji helped to inspire a greater degree of military discipline as he and Liu weeded out opium addicts unable to keep up on long marches and executed bandit leaders who failed to follow orders. They followed up with some basic political education, blaming peasant poverty on exploitation by the rich and powerful. ${ }^{17}$ Even Gao Gang was briefly removed from his commissar post for violation of discipline in the rape of a local woman. This disciplinary action lasted only a few months, however, an indication of Gao's indispensable role in the army and the small price paid for serious violations of local women. ${ }^{18}$ Wang Taiji's contribution to the military capacity of the Twenty-Sixth Army was substantial but short-lived. Soon after Liu rejoined the force, Wang departed, hoping to inspire a mutiny by an army colleague in Shandong; but on the way he was betrayed by a friend and executed. ${ }^{19}$ Liu assumed command, and the army continued to grow. A cavalry unit was organized, and it was able to coordinate quick attacks on local militia with small guerrilla actions against isolated landlords. The cavalry was responsible for several military victories in Gansu; it managed to capture more weapons, and by the end of 1934, Liu's army had grown from 270 to 600 men. ${ }^{20}$

The Twenty-Sixth Red Army was reemerging as a significant military force. However, attempts to reestablish contacts with higher party authorities were unsuccessful, and Liu made little effort to build a local party organization. ${ }^{21}$ According to an early party report on the guerrillas in eastern Gansu, "In the two thousand $l i$ the guerrillas passed through, there was not a single village or town with a party organization or member. The vast majority of the laboring masses 
had no idea what kind of weird thing this Communist army had come to do."22 In eastern Shaanbei, the party was based in rural schools, but schools hardly existed in the small and widely separated villages along the Gansu border. (Even when I visited the area in 1989, the county's largest village had only forty-eight families.) Bao'an, before the Communists expanded the school system, had only one higher primary and four lower primary schools in an area of roughly 3,300 square kilometers; 98-99 percent of the population was illiterate. ${ }^{23}$ The army supported itself by kidnapping wealthy targets for ransom, and Red Terror was mainly directed at local security agents and tax collectors. ${ }^{24}$ Significantly, along the Shaanxi-Gansu border, where education was undeveloped and degree holders were virtually nonexistent, the term gentry (shenshi 绅士) referred to those with power to assess taxes: baozhang (保长) and lizhang (里长). ${ }^{25}$ These were the enemies of the revolution, usually described as "gentry strongmen" (haoshen) in contemporary sources, and the Communists targeted them mercilessly. There was certainly an element of class struggle in this, but it was based, not on any distinction between landlord and tenant, but on links to the state and inequities in power and privilege. Without a local party organization, the struggle against local power holders was not part of any larger revolutionary movement against the ruling class.

\section{A CHANGING POLITICAL CONTEXT}

On the national scene, the most consequential development of the mid-193os was the steadily escalating crisis with Japan and rising domestic opposition to the Nanjing government's pusillanimous response. The 1931 Japanese occupation of Manchuria had been followed by incursions into neighboring Rehe, fierce battles along the Great Wall in Chahar, and Japanese efforts to separate Beijing, Tianjin, and all of North China as a new "autonomous region" independent of Nanjing. Japan's invasion now imperiled more than the distant Manchu homeland; the territorial integrity of the Chinese nation was at stake. After the Manchurian incident, Chiang Kai-shek's government had responded with loud cries of indignation, appeals for League of Nations support, cautious military withdrawals, and carefully negotiated truces with Japan. Initially, there was broad support for his policies, and as we have seen, Communist critics were rendered ineffective when they characterized the Japanese threat as directed against the Soviet Union, for whose "armed defense" they endlessly appealed. Other critics were more effective. Feng Yuxiang rushed to confront the Japanese on the Chahar front, receiving propaganda if not financial support from opinion leaders and militarists in southern China. In November 1933, a rebellion in Fujian opposed Nanjing's appeasement of Japan. Chiang easily crushed the rebellion, but military leaders across the country called for determined resistance to Japanese aggression. ${ }^{26}$

Slowly, the CCP learned from its mistakes. The anti-Japanese movement following the Manchurian incident had largely benefited the party's rivals. In 1932, party propaganda stressed a broad anti-imperialism targeting all the great powers 
that threatened the Soviet homeland, a policy with little appeal to Chinese patriots. Soon the party called for resistance to Japan and chided local operatives for insufficient attention to the growing anti-Japanese movement. ${ }^{27}$ The Red Army was rebranded as a patriotic force. As the Long March left central China, there were calls to "support the Red Army coming north to oppose Japan." 28 These appeals had an indisputable impact in the government's armed forces, whose officer corps included many who had chosen military careers to defend the nation. The most telling evidence of this was the mutiny of Wang Taiji; his officers were angry over Nanjing's retreat from Rehe, were inspired by the students' anti-Japanese demonstrations, and mutinied under the banner of the Northwest Popular Anti-Japanese Volunteers (西北民众抗日义勇军). ${ }^{29}$ As we have seen, only one hundred of the thousand who mutinied stayed with the revolutionary movement, and Wang himself soon left on a fatal attempt to join like-minded officers in Shandong. Nonetheless, his troops and their weapons greatly strengthened the guerrilla movement in northern Shaanxi.

Another important addition to Liu's forces was Guo Baoshan, who also joined under an anti-Japanese banner-though in his case more complex motivations were also involved. Guo led a large "bandit" army of some one thousand men based in the Huanglong mountains north of the Wei River. Guo was a former soldier, whose band was one of those large armies that was periodically absorbed into local warlord commands. Liu Zhidan had long courted Guo, sending a representative with gifts and an invitation to join the Red Army. In the summer of 1934, Yang Hucheng attempted to co-opt Guo's army and those of two other Huanglong "bandits," and the trio fled with their troops to eastern Gansu. There Liu contacted Guo through Society of Brothers intermediaries and again sent gifts, this time three horses. Soon Guo led a company of 120 men to join Liu's cause as an independent force of Northwest Anti-Japanese Volunteers (西北抗日义勇军). After guerrilla victories over the other "bandits" that had fled Huanglong, some of the defeated troops also joined Liu's army. Many of these men had the usual opium addiction of bandit armies, and Guo was allowed to continue smoking, though others were forced to quit or leave. After joining Liu's army, Guo's troops continued to bivouac together, and Liu avoided putting them on the front line in battle. Through such careful measures, Guo's loyalty to Liu and his cause was secured. His men contributed significantly to the victories of 1935, and Guo eventually rose to the rank of general in the People's Liberation Army. ${ }^{30}$ Although Guo's recruitment involved more than anti-Japanese sentiment, patriotism was at least a convenient and credible pretext for joining the revolution.

The national debate over resistance to Japan and Chiang's persistent campaigns against the Communists affected the Shaanxi context in other ways. It is widely recognized that as Chiang's armies chased the Communists across western China, the power of the Nanjing government penetrated areas previously beyond its reach. Chiang's crushing of the Fujian rebellion also increased his power in the 
south. ${ }^{31}$ In Shaanxi, Chiang restricted Yang Hucheng's authority by appointing Shao Lizi governor in 1933. He followed by reducing support for Yang's armies, leading to demobilization orders for twenty thousand soldiers. Now Yang was further threatened by the example of Fujian and the transfer of Chiang's loyal general, $\mathrm{Hu}$ Zongnan, to the Northwest to block the Red Army's northern advance. Feeling his independence in jeopardy, Yang halted aggressive actions against the Communists and even reached out (without success) to Zhang Guotao's Red Army as it passed through southern Shaanxi. ${ }^{32}$ The Shaanbei revolution gained further respite when Xu Haidong's Twenty-Fifth Red Army passed through southern Shaanxi on its retreat from the Hubei-Henan-Anhui Soviet. The Shaanxi Communists hailed this movement as a "victorious advance," and Xu's army briefly made a feint north to threaten Xi'an. The walled provincial capital was certainly beyond the military capacity of Xu's force, but with several thousand well-armed and battle-tested soldiers, his Hubei army was a more formidable force than anything in Shaanbei and proved a significant distraction for Yang Hucheng. Some military units were withdrawn from the southern parts of Shaanbei, giving Liu's Twenty-Sixth Army more room to maneuver. ${ }^{33}$

Finally, there was the weather. For years party documents had maintained that the prolonged drought in Shaanxi provided the objective conditions for revolution. In the words of one 1930 pronouncement, "The rural economy is bankrupt as never before, with endless barren fields abandoned to weeds; five million famine refugees are crying for relief, caught in a trap of hunger, cold, and death. . . . [In these conditions] the revolutionary struggle of the toiling masses unquestionably will expand, hastening the death of the ruling class and bringing complete victory to the revolutionary struggle throughout the province." ${ }^{44}$ In fact, famine rarely leads to revolution: peasants are too weak to fight and devote all their energy just to survive. Large-scale social movements are more likely when subsistence crises come to an end. ${ }^{35}$ In Shaanbei, the drought finally broke when a heavy snow blanketed the land in the winter of 1933-34. For guerrillas in the cold hills above Nanliang, the winter was exceptionally trying; they shivered in unheated caves and struggled to cover their tracks in the snow after an enemy attack. ${ }^{36}$ But snow promised a bumper crop in the summer. That meant ample grain stores for the rich, and ready targets for the guerrillas. It also meant falling prices and less money to pay taxes-taxes that were no doubt increased to make up for the long years of drought. ${ }^{37}$ For these reasons, the end of the drought contributed to peasant grievances and probably left more young men with the will and energy to join the revolution.

\section{THE RETURN OF XIE ZICHANG}

In January 1933, Xie Zichang was sent to Shanghai for reeducation as part of the Xian provincial committee's purge of the Twenty-Sixth Army leadership. What transpired in Shanghai remains hidden in the archives, but Xie was presumably 
cleared of significant wrongdoing and properly reeducated in the prevailing party line. He was sent to Beiping to work with the party's North China representative. In contrast to Liu Zhidan's Shaan-Gan branch of the party, which answered to the provincial committee in Xi'an, the "Shaanbei" party in the northeast had long communicated with the Center through the North China office. ${ }^{38}$ From the towns where the "Shaanbei" party operated, communication with Beiping was faster and cheaper through Shanxi and the rail line to Taiyuan, while it took some two weeks over narrow roads and trails for a courier to reach Xian. ${ }^{39}$ The "Shaanbei" party also received financial support directly from the North China office, enhancing its independence of Xian. ${ }^{40}$ In return, when his guerrillas generated money through kidnapping and ransom, Xie Zichang sent funds to support imprisoned cadres in Beiping. ${ }^{41}$ Xie's assignment to the North China office reinforced these longstanding relations between that office and his branch of the party and was symptomatic of the distinct organizational affiliations of the two northern Shaanxi factions. These separate lines of reporting, funding, and control only served to exacerbate the conflicts between Xie Zichang's "Shaanbei" Communists and Liu Zhidan in Shaan-Gan. ${ }^{42}$

From Beijing, Xie was sent to Zhangjiakou to work in a Nationalist army unit opposing the Japanese advance in Chahar. There he married a well-educated young woman from a wealthy family in Mizhi, a center of women's education in Shaanbei. In the 1920s, You Xiangzhai had taught school in Anding, and Xie had known her there. Later she undertook a number of chores for the party, and Xie sent several letters and proposed marriage. She hesitated, though the party strongly encouraged marriage between comrades. A married couple provided cover for party gatherings, while women who married outside the party risked exposing party secrets. ${ }^{43}$ When the two again came together in Zhangjiakou, a hasty marriage was celebrated. Despite her early admiration of Xie as a revolutionary leader, You was disappointed with her new conjugal life. She found herself cooking, sewing, and mending clothes for a house full of young male Communists. That was not what she had joined the revolution for. Soon the army Xie had joined was defeated in Chahar, the couple returned to Beiping, and Xie was sent back to Shaanbei. The two never saw each other again. A year later, You was in jail in Beiping, pregnant with a child that Xie had certainly not fathered. ${ }^{44}$

In November 1933, the party's North China representative sent Xie Zichang back to revive the guerrilla movement in his native Anding. Soon afterward, Guo Hongtao, from neighboring Mizhi, was dispatched to direct the party organization. ${ }^{45}$ The focus of their operation was an area quite different from the ShaanGan border where Liu Zhidan's guerrillas operated. The northeastern Shaanxi counties along the Wuding and Qingjian rivers were the richest, most densely populated, and best-educated parts of the region. This was also the place where the Shaanbei party had first grown. In the north, along the remains of the Great Wall and the blowing sands of the Gobi Desert, was Yulin, the political center and military base of the local warlord Jing Yuexiu. In Yulin, Jing founded a middle 


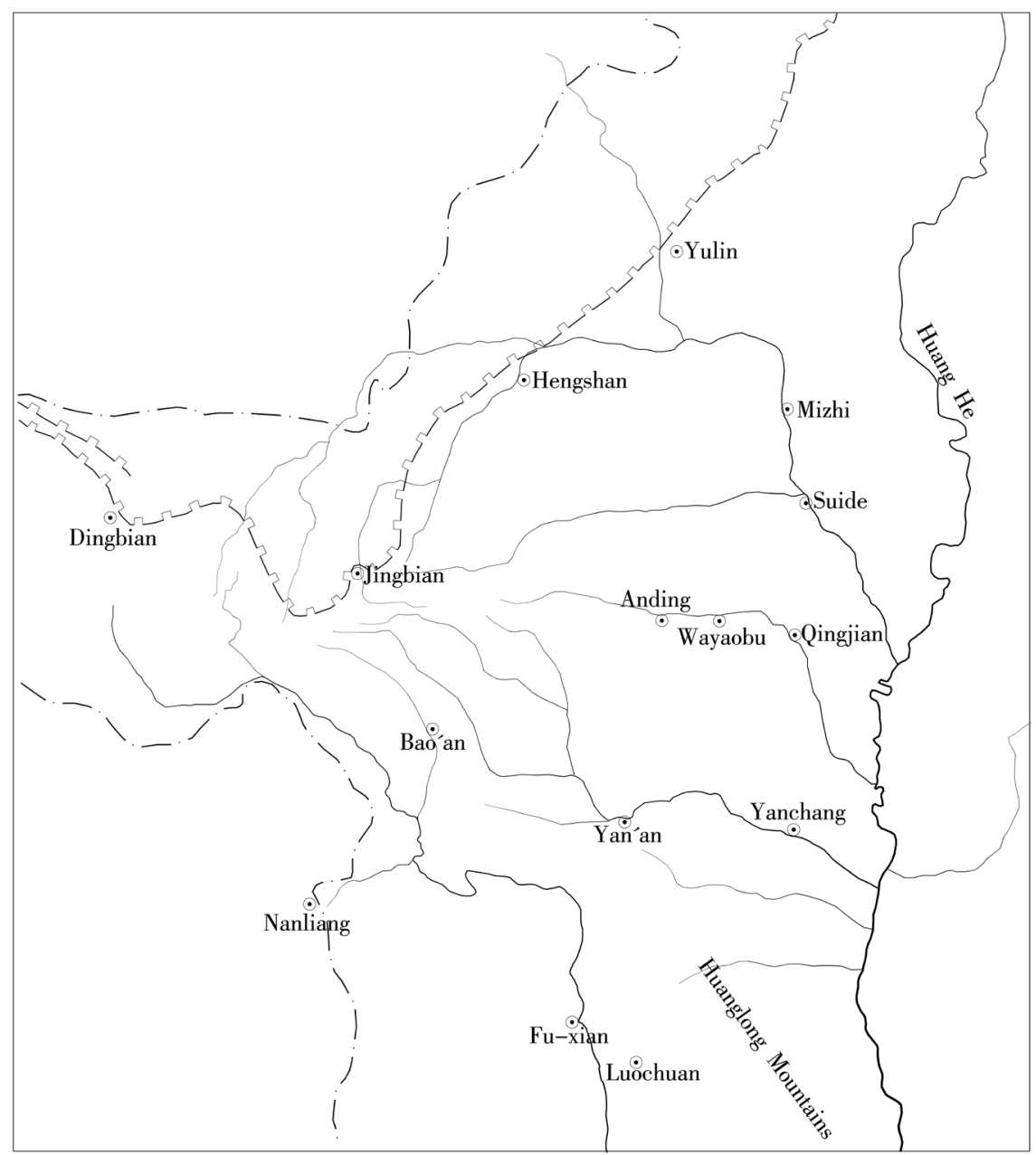

MAP 5. Map of northern Shaanxi.

school to serve the entire region, hiring teachers from Beijing, including Wei Yechou and Li Zizhou, who became the founders of the Communist Party in Shaanxi. As we have seen, both Liu Zhidan and Xie Zichang studied there. Further south along the Wuding River was Mizhi, whose gentry were the best educated and most powerful in the region. Suide, an independent department (zhilizhou 直隶州) under the Qing, had Shaanbei's first normal school, which also produced many Communists until Jing Yuexiu closed it in 1930. Suide and Mizhi were well known for their powerful landlords and a relatively high degree of land concentration. South of Suide was Qingjian, site of a Communist uprising in 1927 and a key ford across the Yellow River to Shanxi. Xie Zichang's home in Anding lay further up the Xiuyan River, west of Qingjian. It prided itself on a cultured and frugal literati tradition that supported a strong school system in the republican era (map 5). ${ }^{46}$ 
While Liu Zhidan's Shaan-Gan revolutionary movement was built from soldiers, militiamen, bandits, and Society of Brothers associates, the Communist Party in northeastern Shaanxi spread through the schools. The northeastern counties had the most and the best schools, and in the 1920s, during the united front with Sun Yat-sen's Nationalist Party, the Communists had been extraordinarily successful in penetrating the educational establishment. ${ }^{47}$ When the counterrevolution came in 1928, most of the leading Communists were killed or defected, but others survived, and sympathy for the early leftist teachers endured. Even in 1933, when 70 percent of the claimed 1,100 "Shaanbei" party members were peasants, party reports admitted that "the entire leadership is still intellectuals, right up to the present." ${ }^{\prime 8}$ One local cadre recalled that workers often defected and that the peasants were ineffective in leadership positions. ${ }^{49}$

Teachers were the reliable heart of the party. Communist teachers at Suide Normal recruited new members who went on to teach in the towns and villages of the area, often protected by sympathetic education commissioners. In Anding, every one of the local cells was headed by a teacher. Through these networks, the party established its rural base. ${ }^{50}$ This intellectual leadership was not without problems, as leftists in the party pointed out: "At that time, party cadres were all intellectuals, and eight or nine out of ten were sons of landlords and wealthy gentry. 'You find your associates, I gather my friends', so the party grew quickly. But the objective result was an organization full of internal conflicts. When they went home, they enrolled their tenants and agricultural laborers. They were the county, district, and local cell secretaries, and all the party propaganda and slogans were only empty talk. If there were any concrete struggles, it would conflict with their own interests." ${ }^{51}$ The party in Shaanbei was expanding through school and family networks deeply embedded in rural society, which produced a village-based organization with all the strengths and weaknesses of a revolutionary movement built on established authority structures.

In the early 1930s, Jing Yuexiu and his conservative supporters had effectively suppressed the party in the northern part of this region, driving them from the schools in Yulin and Mizhi and closing the normal school in Suide after Communist students engaged in the sort of "infantile leftism" typical of this era-leafleting in memory of the 1927 Canton Uprising. A small group of committed radicals persisted, using summer entrance examinations as cover for their meetings, using weddings and funerals as an excuse to travel, stressing secrecy, using passwords, and avoiding regional accents that might expose them away from home. Female comrades were asked to carry secret documents, as they were less subject to search. ${ }^{52}$ Communists lived in constant danger of exposure by defectors. In Mizhi, a Communist who had infiltrated the army as a clerk came under suspicion and was fired by the authorities. The party gave him a minor post, but it did not provide enough to support his wife. Unhappy with his lot, he defected and exposed the entire local organization. ${ }^{53}$ Perhaps as a result of this defection, six Mizhi 
students were arrested and executed in 1933. Their bodies were thrown into the Wuding River, but when they were dragged out downstream there was widespread sympathy for these educated youths. In this area, intellectuals were respected, and killing students - even Communist students-was never popular. There were limits to the effectiveness of White Terror, and the party gained sympathy even as it lost cadres. ${ }^{54}$

Government suppression drove the party from county seats and towns and into the countryside. It also forced the Communists out of the north-most of the small guerrilla operations of the "Shaanbei" party were in Qingjian and Anding, well south of the political-military center in Yulin. The Communists maintained an underground organization in the schools and had some success in supporting tax resistance movements, but in general the guerrilla actions involved very small bands, including the usual bandits and Society of Brothers members. When Yan Xishan launched an opium suppression campaign in Shanxi, the Shaanxi opium porters and guards lost their livelihood, the local economy suffered, and the guerrillas gained another source of recruits. Contemporary newspaper accounts link opium dealers to the growth of the revolutionary movement, and their antagonistic relations with the authorities make this plausible. ${ }^{55}$ Party efforts to discipline these groups could backfire, and one guerrilla organizer was shot by the bandits he was trying to reform. When the party sought alternatives to recruiting bandits, it found that peasants and students lacked the necessary military skills. In combat they just fired their weapons and ran. ${ }^{56}$

Party operatives' awareness of the difference between the "Shaanbei" and Shaan-Gan revolutionary movements is evident behind the inflated language of their reports. In "Shaanbei," "the enthusiasm of the masses is extremely high, now reaching the stage of armed mass action; but our weakness is the lack of weapons." In Shaan-Gan, by contrast, despite an active guerrilla movement, the lack of suitable cadres meant that "we have not generally been able to establish rural branches." ${ }^{57}$ In effect, Shaan-Gan had an army but no party organization, while "Shaanbei" had a rural organization but no army. ${ }^{58}$ The "Shaanbei" party desperately appealed for military support: "In the past, the Twenty-Sixth Army has consistently attacked toward Guanzhong, and has never come to the northern part of Shaanbei. . . They pay attention only to occupying Xi'an." ${ }^{59}$ Of course, it was the provincial committee in Xian that ordered Liu's army to attack Guanzhong; but now that committee had been crushed and Liu had moved north to Nanliang.

By 1934, the road was open to further collaboration, but it was not the first cooperation of the two party branches. Already in 1932, Qiang Shiqing, an Andingborn cavalry officer in Liu's army had returned home to revive the "Shaanbei" guerrilla movement. His first act, soon after the lunar New Year, was the dramatic assassination of the Anding County magistrate. After this, Qiang seems to have moved back and forth between Anding and Nanliang, building a small village-based revolutionary movement in the mountains west of Anding. After 
Liu Zhidan's return in the fall of 1933, Qiang was again sent to Anding with a small force and a little money to support the guerrilla movement there. Qiang, however, was overconfident and foolishly attacked an army unit in Xie Zichang's home village. He was wounded in battle, then sold out by a defector and executed. Others in the band fought on for a time, but they too were defeated. By the time Xie Zichang returned, the group had buried its weapons and disbanded. ${ }^{60}$

When Xie Zichang returned, he chastised his dispirited comrades for abandoning the struggle, dug up the weapons, and led a small band of about ten men to continue the fight in western Anding. As in Nanliang, the winter of 1933-34 was bitter, and Xie suffered from frostbite after sleeping on straw in the hills. The guerrillas could visit the villages only at night; during the day, Xie lectured his men on Shaanbei's history of rebellion and on the Communist movement in Jiangxi, of which he had learned in Shanghai. He reviewed the history of the party and its repeated setbacks, endlessly repeating his favorite slogan: "Defeat is the mother of victory." ${ }^{11}$ When spring came, Xie and his men worked in the fields as peasants during the day, then carried out night raids, gradually building a support network of young Red Guards. ${ }^{62}$ As Xie and others reignited the partisan struggle in eastern Shaanbei, their weapons were few and second-rate, worthless against regular army units. Their targets were yamen runners, tax collectors, and "local despots." 63 Still, this was sufficient evidence of class struggle that the party praised them for overcoming Shaanbei's history of "rich peasant" errors and correctly carrying out the Center's line. ${ }^{64}$

It is notable that this sort of low-grade, small-scale revolutionary movement was as much a family affair as an example of class warfare. The eastern part of Shaanbei had denser and stabler village populations, and kinship ties were more important than in the migrant-filled villages of the west. Activists recruited people whom they knew well and could trust, so they turned first to their own families. It is not surprising that Xie Zichang's deputy commander was his nephew. Indeed, Xie's family was so intimately involved in the revolution that twenty-six of his relatives aided the revolution and nine died for the cause. ${ }^{65}$ Xie's own family was hardly unique in this respect. Another Anding village had five sets of brothers or cousins who joined the revolution, and the lists of local Communists have dozens with identical surnames and generation characters-a telling indication of close kinship ties. ${ }^{66}$ Family loyalty and commitment to the revolution went hand in hand. After his return to Shaanbei, Xie Zichang's most dramatic revolutionary act was a daring assault on Anding to free dozens of imprisoned Communists from jail. Many had been arrested in early 1934 as Xie's guerrilla attacks escalated, and their families appealed for their rescue. In July 1934, Xie led a small band of six guerrillas to break open the jail in the weakly defended county seat-though his own jailed brother may have perished in the attack. ${ }^{67}$ This was, of course, but one side of a pattern in which families became inextricably bound up in the revolutionary process. In its effort to uncover Communist guerrillas, the state would 
arrest family members, holding the family responsible for the radical activities of its young men. The Communists, on their part, kidnapped the offspring of wealthy landowners for ransom and often killed family members of particularly hated strongmen. ${ }^{68}$ The inevitable result was a tangled connection between family bonds and political commitment.

\section{LIU AND XIE: RIVALS AND ALLIES}

Liu Zhidan and Xie Zichang, heroes of the Shaanbei revolutionary movement, were like two stars of a basketball team who never got on the same page. They needed each other to succeed: Liu's military tactics and Xie's organizational discipline would have made a powerful combination. But true cooperation was always just beyond reach. In the summer of 1934, they made one final attempt. Liu Zhidan made the first move, sending weapons to "Shaanbei" in exchange for grain to support his army in Nanliang. ${ }^{69}$ Then, shortly after springing the prisoners from Anding's jail, Xie Zichang led several hundred of his men to rendezvous with Liu Zhidan in Nanliang. Xie's guerrillas were under intense pressure following the Anding attack, and Nanliang provided a reasonably safe refuge. Xie was accompanied by Guo Hongtao, the young Mizhi native who had graduated from the same Yulin school as Liu and Xie. Having spent six years in prison in Shanxi, Guo was relatively inexperienced, but he had learned his Leninism well and was responsible for party-building in "Shaanbei." ${ }^{70}$ Both Guo and Xie had been sent by the North China bureau, where they were briefed on the long history of criticism of the Twenty-Sixth Army for "right opportunism," fleeing to the hills, and failure to carry out land reform. In the past, those criticisms had come from the provincial committee, but now they were advanced by Liu's comrades in the "Shaanbei" branch of the party. The party's ambition was clear: it wanted to gain greater party control of Liu's Twenty-Sixth Army, to unify with the guerrillas in "Shaanbei," and on that foundation to build one great soviet that stretched all the way from Sanyuan in the Wei River valley to the border of Suiyuan in Inner Mongolia. ${ }^{71}$

Given the past conflicts between Liu and Xie, this was a historic meeting. ${ }^{72}$ In 1932, Xie had ordered Liu Zhidan's friend and key officer Zhao Erwa shot at Sanjiayuan. After that incident, most of Liu's bandit-based army had been disbanded and Xie had assumed command. Xie still defended this action, with the "Shaanbei" committee writing in January 1935, "Because Liu's men were all acting like bandits, they were disarmed." ${ }^{73}$ Despite this troubled history, in the summer of 1934, Liu Zhidan welcomed Xie's band with a feast of pork and lamb and an offer of more weapons. ${ }^{74}$ Xie was not impressed. In his report to the party, referring to Liu's army by its new divisional appellation, he charged that "the FortySecond Division has consistently charged about helter-skelter and cannot carry out the hard mass work of the Northwest Soviet."75 The differences between the two leaders were as great as ever. The context, however, was different. Since the 
collapse of the Shaanxi provincial committee, Liu Zhidan had been operating without instructions from any higher party authority. Xie Zichang, however, arrived with the mandate of the Shanghai Center and its North China office. That mandate was embodied in two letters carried by Guo Hongtao.

The letters were based on years of critical reports from the provincial committee about the bandit composition and "opportunist" errors of the Shaan-Gan guerrillas. ${ }^{76}$ The North China message was written in disappearing ink between the lines of an unrelated book - a not uncommon way of transmitting highly secret and sensitive communications. ${ }^{77}$ After deciphering and transcribing the letters, Guo Hongtao carried them to Nanliang, where they were delivered to the TwentySixth Army. ${ }^{78}$ The precise language of the letters is unknown, but similar communications from the time provide a good indication of their content. The consistent tone is resolute optimism about the prospect for revolutionary victory. Though Mao's forces would abandon the Central Soviet just two months later, decisions of the Communist International and the writings of Wang Ming were cited to refute the "nonsense" that the Central Army had suffered defeat in Jiangxi and to argue that urban uprisings were still possible. Small guerrilla actions were criticized as "right opportunism" and as the product of lingering "peasant consciousness." The Shaan-Gan policy of clearing villages and fleeing to the mountains in the face of enemy attack was criticized with the assertion that "defense is the death of revolution." Instead, the Red Army in Shaanxi should prepare to attack towns and cities, eliminating these centers of reactionary armies, while at the same time seeing that "not a single inch of soviet territory is trampled by the enemy." Finally, these letters called for expanding the soviet movement in the direction of the Communist forces operating on the border of Sichuan and southern Shaanxi-unaware that, even as the 1935 letters were written, the Red Army in those areas was preparing to withdraw to Shaanbei. ${ }^{79}$

As these letters showed, the party leaders in the coastal cities were sadly divorced from the reality of revolution in the hinterland. Just a year earlier, Liu Zhidan's forces had suffered a devastating defeat by following similar orders from the party authorities in Xian. Liu was just beginning to have some success in rebuilding his army in Nanliang when he was again accused of right opportunism, hiding in the hills, and neglecting the urban centers. To many of Liu's followers, the message of these letters was a "staggering blow." ${ }^{80}$ Most of the resentment was directed at the young but articulate Guo Hongtao for acting like an "imperial delegate," but some felt that Xie Zichang gave local legitimacy to the twenty-five-year-old Guo and displayed a "factional attitude" in his relations with Liu's army ${ }^{81}$ Later that year the Shaan-Gan revolutionaries counter-attacked by accusing the "Shaanbei" party of ultra-leftism for establishing collective farms while party policy called only for land reform. ${ }^{82}$ While the two factions might have debated their differences on an equal basis, Xie presumed upon the support of Guo Hongtao and his own relations with the higher party organization in Beijing. ${ }^{83}$ Neither the participants' 
memoirs nor the contemporary documents provide any record of the debates in Nanliang, but it is clear that Xie and Guo Hongtao took the offensive in attacking the Twenty-Sixth Army's alleged errors. Given Liu's quiet manner and his consistent obedience to party orders, he is unlikely to have fought back aggressively. On one matter he seems to have given way immediately: Gao Gang was removed as political commissar and replaced by Xie Zichang. Both Xie and Guo Hongtao particularly opposed Gao Gang, with Guo attacking his "vile character" and Xie requesting his reassignment. Gao had been the first representative of the provincial committee to criticize the guerrillas, and despite his later rise and alliance with Liu Zhidan, Xie was no doubt wary of Gao's past affiliation with the hated Xian committee. The fact that Gao Gang had escaped the police raid and destruction of the party committee in Xi'an and fled to join Liu's army probably enhanced Xie's suspicions. Like Xie Zichang in 1933, Gao was ordered to Shanghai for reeducation, but he refused to go. ${ }^{84}$ On other matters as well, Liu and his lieutenants had some success in resisting the orders of their party superiors.

One thing on which Liu and Xie agreed was the folly of continued attacks in the Wei River valley. This had always been the Center's preference, as the best way to threaten Xian and build an urban proletarian revolution. Xie, however, wanted to support his movement in Shaanbei and argued that recent defeats left morale too low for continued attacks in Guanzhong. ${ }^{85}$ Liu agreed that the party should focus on the northern part of the province. In the following months, however, the Center continued to call for attacks on urban centers, and the "Shaanbei" party was

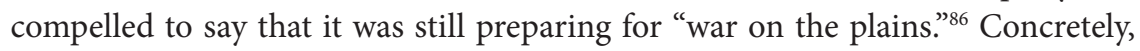
the result of the Nanliang meeting was that Liu Zhidan sent a strong unit under Wang Shitai to support Xie Zichang's struggle in Anding. Wang and his men seem to have returned to Nanliang after a couple months, and Liu and Xie's armies usually operated independently until 1935. Nonetheless, Liu's aid to "Shaanbei" was a significant gesture toward unity and may have dispelled some of the bad blood produced by the July meeting. ${ }^{87}$

After the meeting in Nanliang, Xie Zichang returned to Anding to rekindle the revolutionary movement with the military support of Wang Shitai's men from Shaan-Gan. ${ }^{88}$ The dramatic jailbreak early in the month had brought new attention to the long-dormant resistance to the state. As before, students and teachers provided a core of radicalized youth, and teachers were able to use their status as intellectuals and their local connections to protect the party. With most public appeals focusing on the resistance to oppressive taxation, the efforts enjoyed a certain degree of public support. In Anding, long-standing friendly relations with a local police official delayed the implementation of the Nationalists' efforts to revive the rural baojia public security system. The CCP was able to use the Nanjing government's campaign against corruption and opium smoking to remove a local magistrate. ${ }^{89}$ In the rural areas, the party spread from the villages of party leaders or radical teachers. ${ }^{90}$ Xie Zichang's influence was particularly great around his 
home in the mountainous region of western Anding, and a Chiyuan (Red Origins) Soviet was established there in the fall of 1934. The school system was more developed in the flatter and richer northeastern part of the county, and there a Xiuyan Soviet was established in early 1935 with critical support from teachers and students. But the military-dominated Nationalist government continued to control the area around the county seat, now located in the commercial center of Wayaobu. ${ }^{91}$

According to one contemporary account, half of the villages in Anding and neighboring Qingjian were "Red," and in nearby counties there were ten to fifty Red villages. The spread of the revolutionary movement in the countryside left it in a "stateless" condition. As the party's power grew, it was able to organize Red Guards for sentry duty to protect the local guerrillas. ${ }^{92}$ It is important to note, however, that the party's spread was measured by the number of villages it controlled. This was not a class-based movement that divided landlords and peasants within a village. It was a movement whose strength was determined by whether Communists or conservative elites were able to dominate a settlement. Sometimes this was related to topography: mountainous areas with few or poor roads and far from major towns could become Communist strongholds. In other cases, more schools and radical offspring of elite families were critical. In one case reminiscent of the role of the elite Huang family in Sanyuan, the son of a large landlord in eastern Anding was an underground Communist and also a district head (quzhang) in the local government. The local party cell was located in a school in his family compound..$^{93}$ The result of this process was a patchwork of rural party strongholds scattered across different parts of Shaanbei.

By the end of the year at least seven guerrilla detachments were operating in the "Shaanbei" area. These were relatively small units, in most cases thirty to fifty men in a county, with enough guns for about two-thirds of their members. ${ }^{94}$ However, unlike Liu Zhidan's Shaan-Gan guerrillas, the "Shaanbei" revolution was supported by a substantial local party organization. ${ }^{95}$ Contemporary reports indicate that in July 1933 there were 1,153 Communists in "Shaanbei"; in June 1934, less precise figures indicate over 1,900-2000; and by the end of 1934, there were over 2,200. The largest number, roughly one-third, were in the relatively independent party organization in Shenmu; but the other large concentrations were in Xie Zichang's home county, Anding, and neighboring Qingjian, Suide, Wupu, and Jia-xian. ${ }^{96}$ By and large, the party expanded by recruiting peasant youth from the schools and gained popular support by opposing taxes and official corruption. Still, higher party pressure for land reform was unrelenting, and in some cases it led to senseless excesses. In Qingjian, local cadres banned small commerce and promoted collective farms. ${ }^{97}$ Such measures certainly indicated firm party control of certain villages, but they were unlikely to earn broad peasant support.

While the strength of the revolutionary movement in "Shaanbei" was its rural party organization, Xie Zichang regarded himself as a military leader, and on his 
return to Anding he immediately resumed his guerrilla activities. ${ }^{98}$ Barely a month after his return, he led an attack on a well-defended ford on the Yellow River at Hekou. He was shot in the chest but tried to conceal the wound with a woman's purple jacket (presumably confiscated from some wealthy family) that did not show the blood stain. Even after abandoning the fight at Hekou, he continued to lead his men in battle. He is credited with the first successful seizure of a county capital, when Anding, now lightly defended as most troops had been moved to nearby Wayaobu, was briefly taken in September. ${ }^{99}$ By winter, infection from the wound seems to have spread and Xie was forced to retire from the field, protected by family and comrades until his death in an isolated mountain cave on February 21, 1935. ${ }^{100}$ As Xie Zichang lay dying, Liu Zhidan paid him a final visit. At the meetings in Anding, a unified command for all of northern Shaanxi was established. Liu and Xie reportedly deferred to each other's leadership of the military committee, and memories differ on who prevailed. In the end, it seems, Xie was appointed with Liu acting in his place while he recovered from his wounds. Most likely, Liu saw that Xie would not survive, so he was content to forgo the immediate honor of the formal title. ${ }^{101}$

Following Xie's death, there was no funeral, despite the family's wishes. The party feared a blow to guerrilla morale and did not wish to give the Nationalists an opportunity to claim victory. The strategy worked for many months, as Nationalist internal communications continued to refer to Xie as late as August $1935 .{ }^{102}$ Though Anding County was not officially renamed Zichang until 1942, the local party authorities had anticipated this decision in 1935, and surviving documents refer to such a county, in northwestern Anding. ${ }^{103}$ It is clear that Xie Zichang had a significant reputation in and around his base in Anding, but the basis for that reputation remains somewhat puzzling. There was nothing heroic in Xie's physical appearance. All surviving photographs reveal a thin, pale-faced young man who looks more like a student than a guerrilla commander. His comrades' memoirs recall his short, thin, and slightly stooped stature and youthful face. ${ }^{104}$ In declining the post of political commissar, he claimed to be more a military than a political leader, and it is certainly true that most of his career was spent in military roles: as a militia commander in Anding, as an officer in warlord armies in Gansu, and with the guerrillas. He seemed to believe that status and power in Shaanbei lay with the military-and in this he was not mistaken. His military record, however, was far from distinguished. In 1932 he was removed for the failed attack on the walled town of Shanhe in Gansu, and he commanded the forces defeated in Baoan at the end of the year. As one party historian confided, "Some people say Xie Zichang never fought a winning battle." 105 Though memoir accounts generally refrain from direct criticism, they mention low morale from frequent changes of command, often at times when the change was the appointment of Xie. ${ }^{106}$ Finally, of course, the attack on Hekou where he was mortally wounded can only be described as foolhardy. 
Newspaper accounts in the Guomindang press repeatedly mention battles against Liu Zhidan's guerrillas, and one article carried the title "Shaanbei Bandit Chief Liu Zidan."107 The "Communist bandit" most feared by the state was Liu Zhidan. Xie Zichang's name hardly appears. One cannot escape the suspicion that Xie's persistent criticism of his Communist rival was in part motivated by jealousy of Liu's loftier reputation. Xie was confident of his own political correctness, but he seemed to feel a need to demonstrate his military credentials. In the end that effort, plus his undeniable physical courage, proved to be his undoing. Xie was certainly more in tune with his superiors in the party, and in his final year in Shaanbei he was acting with the full support of the party apparatus. Now, however, Xie Zichang was gone, and Liu Zhidan's military command had no rival in the party. The road was open for the guerrilla movement to expand. On the other hand, the time had also come for Chiang Kai-shek and the Nanjing government to turn its attention to Shaanxi.

\section{NATIONALIST EXTERMINATION CAMPAIGN \\ AND COMMUNIST RESPONSE}

In the early 1930s, Chiang Kai-shek's anti-Communist campaigns concentrated on the soviets near the political and military centers of the Yangzi valley. These early military operations were briefly interrupted by the Japanese occupation of Manchuria in 1931, but by the fall of 1932, Chiang's armies had driven Zhang Guotao from the Hubei-Henan-Anhui Soviet, and two years later, Mao, Zhu De, and Zhou Enlai were forced to abandon the Central Soviet in Jiangxi. With the Central China Communists on the run, Chiang turned his attention to Shaanxi.

Major extermination campaigns against the northern Shaanxi soviets began in 1935, with the second encirclement in February and the third in July. The first of these mobilized twenty divisions and targeted the relatively independent Communist base in the far northeast counties of Shenmu and Fugu, which was effectively eliminated. ${ }^{108}$ In other parts of the region, the campaign had less success, and in July the third encirclement mobilized over one hundred thousand soldiers against a Red Army with at most one-tenth that number. The strategy called for the encirclement and gradual strangulation of the Shaanbei guerrillas, with the Muslim armies of Gansu-Ningxia warlords Ma Hongkui and Ma Hongbin attacking from the west, Yan Xishan sending troops across the Yellow River from Shanxi to the east, Jing Yuexiu exerting pressure from his Yulin base in the north, and Yang Hucheng, joined by the Northeast Army of Zhang Xueliang, moving up from the Wei River valley in the south. ${ }^{109}$ To strengthen the local forces in Shaanbei, Chiang dispatched a division under Gao Guizi, a native of the area, though his troops were from the North China plain. Gao established his headquarters in Suide, and an airfield was built to speed communications and permit reconnaissance and bombing operations. ${ }^{110}$ 
The total military force assembled against the Communists was unprecedented in size but consistently marred by internal rivalries and petty jealousies. Jing Yuexiu had long been the master of Shaanbei and had managed to prevent any Nationalist Party interference. The Xian authorities were also wary of Jing's independence and sought means to control him. Gao Guizi was a Shaanbei native who had been forced out by Jing. Now he was sent back to check the power of his former commander. Gao, however, had been sent by Nanjing, and Yang Hucheng in Xian did not necessarily welcome Nanjing's influence in the province, which had increased with the 1933 appointment of Shao Lizi as governor. Finally, of course, the armies of the Ma warlords and Yan Xishan had no real commitment to the struggle in Shaanxi and were, in any case, regarded by the local population as intruders. The result was a web of rivalries among national, provincial, regional, and local forces that made any coordinated military effort challenging. ${ }^{111}$

Despite the lack of coordination, the increased attention and new state resources brought real change to the Shaanbei environment. Chiang Kai-shek sought to institute his new anti-Communist policy of gradual step-by-step strangulation of the enemy through a network of well-defended blockhouses. To link these military strongpoints, roads were built and phone lines strung to improve communications. The population was moved from isolated mountain villages into strategic hamlets-larger, well-defended settlements - and a headquarters to coordinate all of this was established in Suide, with its new airfield. ${ }^{112}$ The Nationalist slogan called for an anti-Communist strategy that would be 70 percent political, with tax remissions, road passes for good citizens, and better military discipline to prevent abuse of the population. ${ }^{113}$

For Liu Zhidan in his Nanliang base, the greatest threat came from $\mathrm{Ma}$ Hongbin's troops in Gansu. As noted above, the area around Nanliang was sparsely populated. When the southern armies from Hubei or Mao's Long March passed through in 1935, they marched for days on end without finding a single village or source of food. ${ }^{114}$ Now Ma Hongbin's army occupied the fortified towns and moved the sparse rural population into strategic hamlets, depriving Liu's Red Army of its popular base. If the guerrillas were the proverbial fish in water, the encirclement campaign was drying up the water. The guerrillas' only response was to move residents of smaller isolated villages, together with their food and animals, into the hills to protect Red Army supporters from enemy reprisal. ${ }^{115}$ Even so, Ma Hongbin occupied most of Liu's home county in Bao'an. A unit was sent to dig up the Liu family graves; and Liu's father, never a fan of his son's revolutionary activities, was led into the Nanliang hills, where he grumbled at the primitive conditions and lack of opium, cursing his "bandit son" (zei wazi 戌娃子). ${ }^{116}$

After suffering defeat by the Ma warlords' cavalry, the nascent soviet in eastern Gansu was abandoned, and the Communist remnants withdrew to the lower 
reaches of the Luo River basin in Qanquan and Ansai. Ansai was the poorest county in the region with a notoriously weak government. ${ }^{117}$ The enemy controlled the fortified towns, but south of the river was forest, which provided cover for the guerrillas and removed the advantage of Ma Hongbin's Muslim cavalry. The guerrillas were able to organize in the villages, then escape into the forest when the enemy approached. Organizing of the peasantry also improved, so that young Red Guards were able to provide intelligence and act as sentries. ${ }^{118}$ As always in this region, many of the guerrillas were recruited from bandit gangs and the Society of Brothers. With the soviet government relying on expropriations from the wealthy, the soviet itself was acting like a bandit regime, and some local bandits even claimed to be Red Army guerrillas. The Communists, however, were resolutely trying to escape their bandit past, and some of these "Communist" bandit gangs were infiltrated and then eliminated, their leaders killed and the others disarmed and dismissed. ${ }^{119}$

The Bao'an-Ansai section of the Luo River was the one area in Shaan-Gan where Liu Zhidan's guerrillas were able to establish a sufficiently stable regime to attempt land reform. Higher party authorities had long accused Liu's forces of neglecting this policy, and initially this was certainly the case. The head of the land reform committee was a migrant from Hengshan who had gotten wealthy during the revolution and regarded rich peasants as people who profited from their own hard work. This was too generous a view even for Liu, and the cadre was soon removed. ${ }^{120}$ By 1935, Liu himself was campaigning elsewhere, but his brother Liu Jingfan was the local party secretary and responsible for land reform. Liu Jingfan's recollection reflects the moderate policy that he applied. From the time of the Muslim rebellions, "Sparse population over a wide area was a defining feature of the Shaan-Gan region. .. . There were few people and plenty of land. As a result, the people's demand for land was not that great; their greatest concern was eliminating debt and redistributing movable property." The party stressed burning land and loan deeds and redistributing grain, draft animals, sheep, and other property. In redistributing land, only rented valley land was affected, and confiscated land was usually simply given to the tenant. There was no demand for the unirrigated hill land, and it was left to the original landholder. ${ }^{121}$

Despite the precarious survival of a small soviet in the Luo River area, the arrival of Ma Hongbin's army fundamentally altered the balance of power on the ShaanGan border. For years this had been a no-man's-land, too far from the Shaanxi authorities in Xian, Jing Yuexiu in Yulin, or the Gansu militarists in Lanzhou for any of them to pay much attention. Chiang Kai-shek's intervention changed all that and made it impossible for Liu Zhidan's Twenty-Sixth Red Army to survive in the region. Just at this time, however, Xie Zichang lay dying in Anding. For Liu, that provided a new opportunity and a new area to expand. So early in 1935, the center of Liu's operations shifted to Xie's homeland in the northeast of the province, and with that, a new stage of the revolution began. 


\section{LIU ZHIDAN IN “SHAANBEI”}

The shift to the northeast came with a new organizational structure that unified party operations in northern Shaanxi. In 1934, there were two separate party committees: the Shaan-Gan and Shaanbei special committees (tewe $i$ 特委). At a February 1935 meeting in Anding, acting on a directive from the North China representative, a new CCP Northwest Work Committee (中共西北工作委员会) was formed. Hui Zijun, a worker from the Xi'an arsenal who had joined the guerrillas in Zhaojin and operated the machine shop there, was named secretary. Hui, however, was also the secretary of the Shaan-Gan party committee, and when he returned there, Cui Tianfu, a peasant from "Shaanbei," acted in his stead. Both of these were largely ceremonial appointments, to satisfy higher party authorities' insistence on worker-peasant leadership. Real power lay with the other members of the committee, which preserved a rough balance of the two factions, with five from Shaan-Gan and four from "Shaanbei"; but with Xie Zichang on his deathbed, the "Shaanbei" faction was substantially weakened. "Shaanbei," however, gained from Guo Hongtao's service as confidential secretary (mishuzhang 秘书长) and head of the Organization Department, which controlled party appointments. ${ }^{122}$

The real power of the Shaan-Gan group was the Red Army. A Northwest Military Committee was established with authority over both Liu Zhidan's Twenty-Sixth Army and Xie Zichang's newly formed Twenty-Seventh Army; and while the official chair may have been the dying Xie Zichang, it was Liu who acted in his stead, with Gao Gang as his deputy. In the army, then, Liu Zhidan and the Shaan-Gan group were now in command. This committee directed Liu Zhidan to shift his operations to "Shaanbei," which he was happy to do given the intense pressure on Shaan-Gan from Ma Hongbin's armies. ${ }^{123}$ In addition, the new Northwest Work Committee endorsed anti-Japanese as opposed to general "anti-imperialist" policies, condemning recent Nationalist Party concessions to Japan and accusing the new government command in Suide of being a "Japanese imperialist intelligence staff." ${ }^{24}$ Liu Zhidan's preference for a broad anti-Japanese united front was clearly gaining strength.

In northeastern Shaanxi, Liu targeted the weakest link in Chiang Kai-shek's encirclement campaign. Chiang had dispatched Gao Guizi's Eighty-Fourth Division from the North China plain to garrison Suide and eliminate the Communists in the area. Gao was from Shaanbei, a former subordinate of Jing Yuexiu, and this was a key reason for his appointment; but the move revealed a certain ignorance of the complex local politics. For one thing, Gao's long-standing rivalry with Jing made cooperation between the two officers problematic. ${ }^{125}$ In addition, Gao came from the province's far northwest, along the Inner Mongolian border, and paid greatest attention to this area, dispatching troops there and weakening the forces in the northeast, where they were most needed. ${ }^{126}$ Perhaps most critically, while Gao was from Shaanbei, his troops were from the North China plain and quite unused to the tactics of mountain warfare. ${ }^{127}$ Finally, the poorly supported troops 
were forced to rely on the opium trade to fund their operations. In the words of one Nationalist inspector, the entire military effort in Shaanbei was in crisis:

Public servants dare not enter the countryside; on the road they need an army escort. Trade is at a standstill, tax collection is sharply reduced, and alarms follow one on the other. Then look at the army: either planting opium, guarding opium shipments, or protecting travelers for easy profit. Everybody pursues his own interest. Even company or platoon commanders have their families with them; regiment and battalion commanders never meet their troops; they are sloppy and dejected, totally lacking in energy. The division is the brains of an army, but they have no plan to eliminate the bandits. The units do not work together, always avoiding responsibility. The key staff members are without a care in a cloud of opium smoke, glossing over problems and saying all is well, denying the Communists are even a threat. ${ }^{128}$

To confront this large but incompetent military force, Liu Zhidan could rely upon a significant rural party apparatus in "Shaanbei." In "Shaanbei," unlike Shaan-Gan, the school-based rural party organization was well developed. As the Nationalist army occupied the towns and built blockhouses to protect the larger villages, the Communists continued to operate in the countryside. ${ }^{129}$ Even the leading organs of the "Shaanbei" party retreated to the countryside until such towns as Yongping were taken later in $1935 .{ }^{130}$ Gradually the party strengthened its network of cells at the county, district ( $q u$ ), and township (xiang) levels. ${ }^{131}$ It should be stressed, however, that the party by no means controlled all of the countryside in northeastern Shaanxi. There was, instead, a patchwork of "Communist villages" where the party's strength was built upon the local influence of leftist teachers or prominent Communists. ${ }^{132}$ One plausible memoir says that in fact only one-tenth of the villages were under Communist control. ${ }^{133}$ In areas of Communist strength, new counties were created. In Xie Zichang's home county of Anding, important strongholds west of the capital became Chiyuan ("Red Origins)" County, and a new Xiuyan County was organized in the northeast. ${ }^{134}$ As noted above, the party's greatest strength was around the homes of such prominent leaders as Xie Zichang or the party secretary of the region, Cui Tianfu. ${ }^{135}$ The area around Anding was certainly a stronghold. According to a Nationalist official's report, "On [January] 24, [1935], I traveled from Wayaobu to Anding. . . . West of Qingjian, all is Communist controlled. ... Along the road there were many slogans of the Communist bandits. You cannot travel more than a few $l i$ from the town. ... The situation in Anding is even worse than Qingjian. The bandit force was at first not very powerful, but the people have been transformed and blindly follow the bandits, and their organization is very strong." ${ }^{136}$ In these Communist-controlled areas, new recruits were organized as Red Guards to serve as sentries. When the enemy came, the party would empty the villages and retire to the hills, protecting the population from tax collectors or military requisitions. ${ }^{137}$ This was a defensive posture that the higher party often condemned, but it was no doubt welcome if it protected the population from exactions by the state. 
When Liu Zhidan brought his Red Army forces to the northeast in 1935, the revolution was radically transformed. Military power allowed the Communists to control ever-expanding portions of the countryside and to recruit aggressively. One document from June 1935 claims that 70 percent of the adult male population had joined the Red Army and that seventy thousand in Shaanbei were in the party. ${ }^{138}$ These rough figures were certainly inflated, but they suggest that most of the party membership was in the northeast, for another report from the end of the year listed only two hundred party members in Liu's Twenty-Sixth Army and three thousand in the Shaan-Gan soviet. ${ }^{139}$ The expanded party membership supported Red Army recruitment. The regional soviet set aggressive army recruitment goals, asking each county to add thirty to sixty soldiers in successive fifteen-day periods, with similarly optimistic quotas of three thousand per month for the entire Shaanbei soviet. ${ }^{140}$ When a journalist entered the area in 1936, he reported that "almost all able-bodied males follow the Red Army." 141

While the party may have fallen short of these high recruitment quotas, there is little doubt that many peasants joined the party in 1935. Yanchang County records from 1948-49 describe seventy-nine rural cadres who joined the party before the Shaan-Gan-Ning Border Region was established in 1937. Seventy-three of these (94 percent) joined in 1935-36, and sixty-five (82 percent) in 1935 alone. The vast majority of these were poor and middle peasants under the age of thirty, so teenagers in $1935 .{ }^{142}$ Party leaders, we know, came mostly from educated families: Xie Zichang, Ma Mingfang, An Ziwen-to name only the most prominent from Shaanbei-were all educated men from locally prominent families. ${ }^{143}$ The party admitted that the local leadership was entirely composed of intellectuals, with teachers playing a key role. But in the shock recruitment campaigns of 1935, the net was cast much wider, even indiscriminately. Many of the new recruits were, predictably, bandits. ${ }^{144}$ The rest were young males, usually teenagers, who often joined for purely personal reasons: the death of a father, troubled relations with a new stepmother, or unhappiness in an adopted family. It may be significant that several of the leaders for whom we have biographies were orphaned at a fairly early age. ${ }^{145}$ Some were attracted to the excitement of life with the guerrillas: "it was the fad” (gan shimao 赶时髦), said one informant. Small guerrilla bands passed through his village, and it looked like an exciting sort of life. Others were hungry at home and discovered that with frequent raids on landlords, the guerrillas ate better than ordinary peasants, even feasting on slaughtered lambs. ${ }^{146}$ The party, however, wanted some assurance of revolutionary commitment; thus according to a contemporary party document in some areas, "When the suffering masses came to find the Communist Party, killing gentry strongmen was the condition for joining." ${ }^{47}$ One cadre recalled: "At that time . . . , left was always better than right. When you went down to work, you had to kill people. Killing people was the standard. If you didn't dare kill people, you were at least a rightist, or wavering; you might even be given the 'right liquidationist' label."148 
The result, in 1935, was a period of intense internecine warfare, largely along class lines but mediated by complex webs of party, village, and family loyalties. The party organization had long railed against the "rich peasant" line in Shaanbei, and now it claimed success. ${ }^{149}$ While in Shaan-Gan, Liu Zhidan had mostly kidnapped the wealthy for ransom, but now gentry strongmen and local tax collectors were publicly executed at mass meetings. ${ }^{150}$ According to one leftist recollection: "During the land revolution in Anding, anyone who had been a district head, or 'gentry', all local strongmen and evil gentry were killed. Only those who fled or had already died could escape. Landlords and some rich peasants, plus a few rich middle peasants, were also eliminated during war, the land revolution, the campaign against counter-revolutionaries, or land redistribution. In the whole country, Anding was probably the only county that eliminated all trace of local strongmen and evil gentry, corrupt officials, clerks, and landlords." 151 This no doubt exaggerated the efficacy of class warfare in Shaanbei, or conflated 1935 with later episodes of class warfare. Still, another account from the Guomindang side claims that all officials, teachers, gentry, merchants, and usurers were executed. ${ }^{152}$ Since local cadres were selected from middle school and higher primary school students, most of whom came from wealthy families, and since members of such families who supported the revolution were exempt from land distribution, it is clear that political as well as class distinctions governed revolutionary violence. Nonetheless, even this account admitted that there were leftist errors of "indiscriminate arson and executions." ${ }^{153}$ Explaining the execution of a bankrupt opium-addicted landlord, one peasant explained: "It was like that in 1935. If someone said something against you, you got shot." 154

For a time, the region descended into a brutal cycle of revenge killings-Red Terror countered by White Terror. In one well-documented incident, three brothers who had oppressed the people as tax collectors and allegedly raped local women were seized and bludgeoned to death with a shovel. The physical viciousness of the attack was striking: the local leftists lacked a knife and feared that a gunshot would attract the authorities' attention. ${ }^{155}$ After guerrilla executions of landlords, militia heads, and members of a hated strongman's family, Gao Guizi's Nationalist forces in Suide organized in defense. A wealthy Communist defected, and his information led to the arrest and public execution of twelve Red Guards on a crowded market day. This cruel act aroused public anger, and the Communists called for revenge, seizing two hundred village functionaries and killing thirty-two. ${ }^{156}$ In this murderous struggle, captives were routinely executed, and the Communists admitted "frequent violations" of discipline, including abuse of the people, rape, and appropriation of stolen property. ${ }^{157}$ The Nationalists also admitted that profiteering and abuse by their soldiers drove many peasants into the Communist camp, and they routinely hung the heads of executed Communists from city walls. ${ }^{158}$

There is little doubt that this spreading wave of political violence was linked to the growing power of the Red Army. In some areas, local cadres were reluctant 
to institute land reform until the party had military control. Peasants feared the return of landlords, the loss of redistributed land, and likely retribution. ${ }^{159}$ In this sense, the escalating social conflict was intimately connected to the success of the Red Army on the battlefield. By mid-1935, Xu Haidong's Twenty-Fifth Army from Hubei was ending its sojourn on the Shaanxi-Sichuan border and headed into Gansu and eventual union with the Shaanbei revolutionaries. Xu's advance drew off some of Ma Hongbin's forces that had been attacking the Nanliang base. ${ }^{160}$ This reduced the pressure on the Luo River soviet and allowed Liu Zhidan to focus on the campaign in the northeast. Liu did not, however, entirely abandon his old base on the Shaan-Gan border, and his cavalry still made long-distance raids on eastern Gansu for money and supplies. ${ }^{161}$

In Shaanbei, Liu's strategy was to harass Gao Guizi's Suide-based forces whenever they ventured forth to patrol the countryside. The object was to confine them to their garrisons and blockhouses, leaving the villages open to Communist organizing. The spreading network of young Red Guard sentries made this tactic increasingly effective, as the Communists were warned whenever the enemy ventured forth. ${ }^{162}$ With his forces confined to blockhouses, Gao had to arrange supply trains to support them, and these became targets for ambush. After a few such incidents and significant losses of supplies and ammunition, some strongpoints were abandoned, most significantly the small Anding County seat, with the government withdrawing to the larger nearby town of Wayaobu. With this, the Communists gained relatively secure control of their first county seat in Shaanbei. ${ }^{163}$ With Wayaobu now isolated, a supply column was ambushed, with the capture of several officers' wives. To secure their release, the Nationalist army surrendered weapons to the Red Army. Soon another supply train heading for Yanchuan was ambushed, adding more guns and ammunition to the Communists' arsenal. ${ }^{164}$

The victories by Liu Zhidan's forces greatly increased their fighting strength. While they used to enter battle with more men than guns and tightly rationed ammunition, now they had enough rifles and a reasonable number of highly prized machine guns. The machine guns permitted the concentrated firepower necessary to overwhelm fortified positions, and the mortars were their first artillery. The new weaponry certainly changed the nature of this guerrilla army, but there remained certain incentive systems from the bandit/guerrilla past: the unit that captured weapons was allowed to keep them. ${ }^{165}$ Victories over regular army units also brought valuable trained soldiers into their forces. Captives were given three options: join the Red Army, return home, or rejoin their units and promise to shoot in the air in future engagements. Special efforts were made to recruit medics and soldiers with experience using machine guns. ${ }^{166}$ This lenient policy toward captives was partly the product of necessity: there was simply no way to confine and feed a large number of prisoners of war. It was also politically effective, as released soldiers convinced their comrades that the Red Army posed no 
threat to ordinary soldiers. ${ }^{167}$ Officers were not treated so kindly, and many were simply executed. When a Whampoa classmate of Liu Zhidan pleaded for mercy, Liu bluntly ordered, "Kill the bastard."168

With his success, Liu Zhidan's confidence grew. Now he was ready to attack county seats and establish a more unified soviet regime in Shaanbei. The first target was Yanchang, lightly defended despite its treasured oil fields, then small and poorly served by any viable transport. Red Guards and local guerrillas drew off the local militia, then Liu attacked and took the town with his main force, holding it for four days in late May. The magistrate and several local strongmen were executed, and a large quantity of money was seized. ${ }^{169}$ Further victories followed quickly in June. Neighboring Yanchuan was abandoned by the Nationalists and briefly occupied. ${ }^{170}$ From there, Liu's armies swung north, again occupying Anding before moving on to small and weakly defended Ansai, which was easily occupied with the usual execution of county officials and local elites. ${ }^{171}$ Finally, after a fierce battle, Jingbian on the old Great Wall was taken after heavy losses. This was the first instance in which Liu called on the former bandit Guo Baoshan to commit his forces, which he did, despite substantial casualties. Jingbian was a major military stronghold in the north, and once it fell, Bao'an and Dingbian also succumbed to the Communist assault. ${ }^{172}$ These successive setbacks brought the Shanxi warlord Yan Xishan into the struggle, as he was induced to send troops across the Yellow River into Shaanxi. The result was much the same. In July, the Shanxi troops at Dingxianyan, a town on the road to Suide, were besieged and Liu then executed a successful ambush of the relief column. Two hundred were killed, another 1,800 captured, and a vast quantity of weapons, including fifty machine guns and some mortars, were captured. Following this defeat, Yan Xishan withdrew most of his troops to the safety of his native province. ${ }^{173}$

In two short months in the summer of 1935, Liu had taken, however briefly, seven county seats in Shaanbei. By the fall of 1935, the Communists claimed soviets or revolutionary committees in over twenty counties in northern Shaanxi and eastern Gansu. ${ }^{174}$ A Nationalist report from August 1935 indicates the extent of Communist power following Liu Zhidan's impressive string of victories. It estimated a total guerrilla force of twenty thousand men (certainly an exaggeration of the main force units) with forty to fifty machine guns. Most of these were in the hills, harassing the Nationalist forces, but the extent of their control was sobering:

Bao'an, Ansai, Anding, Qingjian, Fushi [Yan'an], Ganquan, Yanchang, Yanchuan, and Fu-xian are almost completely Communist controlled. Anding is the center, and the location of their government. In the Communist areas, they are already distributing land to the peasants. They have established control of education, culture, the economy, and grain. In Yulin, Hengshan, Suide, Mizhi, Shenmu, Fugu, Jia-xian, Wupu, Zhongbu, Luochuan, Dingbian, and Jingbian, half of the area is Communist controlled, half is a guerrilla area. [The Wei River counties of] Hancheng, Chengcheng, Baishui, Yichuan, Yijun, Tongchuan, Yao-xian, Xunyi, and Chunhua are all guerrilla 
areas. In the Communist areas, the people all follow these bandits. There are Young Pioneers, Red Guards, propaganda teams, support for the wounded, canteens, and teams for washing and mending clothes. ${ }^{175}$

Yan'an was now effectively surrounded by a Communist-controlled countryside. The Nationalist officials in the area admitted that they were losing the battle: "People are losing confidence that the army can protect them." ${ }^{176}$ But the Nationalists were also divided among themselves. The civil officials blamed the army. Shortly before his own county fell to Liu Zhidan's assault, the Yanchang magistrate complained that after suffering several defeats, Gao Guizi withdrew his forces to the towns and would not answer appeals for help. "Since Gao's division came to Shaanbei, the rebels' arms have increased by two thousand. Before, the rebels had no good guns; now they have machine guns and rifles, all lost by Gao's troops."177 The army, for its part, blamed the civil authorities: "Corrupt officials and clerks, local strongmen and evil gentry collude in their crimes, oppressing the people so that the masses of workers and peasants cannot bear it any longer and succumb to the Communist propaganda." 178 With the Communists winning battle after battle and the Nationalists in disarray, the tide had finally turned in Liu Zhidan's favor. But soon, once again, he would have to contend with critics within his own party.

\section{THE PARTY TAKES COMMAND}

In July 1935, as Liu Zhidan was completing his victorious campaign across Shaanbei, two representatives from the Shanghai party Center arrived in the area. The first and most important of these was Zhu Lizhi, a twenty-eight-year-old native of Nantong, across the Yangzi River from Shanghai, who had joined the party in 1927 while studying economics at Beiping's elite Tsinghua University. Zhu carried with him five letters of instruction from the party Center, written between January and May 1935. Upon arrival, Zhu conferred with the North China representative, Guo Hongtao, to understand the local situation. While Zhu was a Beijing-trained intellectual from the lower Yangzi, Guo was a Shaanbei native with presumed understanding of the local scene, and their alliance was later characterized as that of an "imperial commissioner" and a "local emperor."179 Zhu also emboldened the young and ambitious Guo Hongtao, telling Guo that he had learned in Shanghai that the way to rise in the party was by attacking one's comrades. ${ }^{180}$ In a series of speeches that lasted three and a half days, Zhu conveyed the thrust of the Center's letters. If anything, the errors of Liu Zhidan's Shaan-Gan soviet were made more serious than ever. The previous "right opportunism" now become "right liquidationism” (右傾取消主义), that is, seeking to eliminate (liquidate) the party's leading role-an error that Lenin had attributed to the Mensheviks. In the Leninist jargon of the April letter, "There is right liquidationism in the Shaan-Gan party; their conspiracy has been exposed. ... A liberal attitude toward right liquidationism and opportunism represents benevolence toward the imperialist rich peasant 
line and cruelty toward the revolution." The letter called on the Shaanbei party to combine with the south Shaanxi-Sichuan soviets so that they could "open an international connection through Xinjiang and Inner Mongolia," once again looking for Soviet assistance to save the revolution. ${ }^{181}$

After his string of military victories in the summer, Liu Zhidan displayed an uncharacteristic assurance in the face of his party superiors. In the past, he had obediently followed orders from higher party authorities, leading his troops on futile and ultimately disastrous attacks on the Guanzhong plains, even south of the Wei River. Now he resisted the Center's renewed attacks on his rightist errors. The Shaanbei party was excoriated for the "unforgivable error" and "crime against the revolution" of "ignoring preparations for urban uprisings." ${ }^{182}$ Nonetheless, when Zhu called for attacks on Yan'an, Wayaobu, and other walled towns in Shaanbei, Liu and his officers refused: their army was simply not equipped for such assaults. ${ }^{183}$ While Zhu wanted to open a northern link to the Soviet Union, Liu's concern was the Northeast Army advancing from the south. Some were openly dismissive of these new edicts from a dogmatic and uninformed Center. Huang Ziwen, who had led the Sanyuan organization and was now a political officer with Liu's army, attacked the "kids in charge" of the Center after the 1931 plenum-an unmistakable reference to the young and inexperienced Wang Ming. Zhu took such resistance as confirmation of rightist errors, but initially he was powerless to act. ${ }^{184}$ That situation would soon change.

In September, Xu Haidong's army from Hubei arrived, and now Zhu and Guo had the military support they needed to deal with Liu Zhidan. Xu and his TwentyFifth Army came from the Hubei-Henan-Anhui Soviet, which had witnessed some of the bloodiest violence of the Communist revolution, including summary purges of local revolutionaries deemed untrustworthy. ${ }^{185}$ When Edgar Snow met $\mathrm{Xu}$ in 1936, he described him as "the most strongly 'class-conscious' man ... of all the Red leaders I met." ${ }^{186}$ Xu's first contact with the Shaanxi revolutionaries came when an underground Communist agent, an officer in Yang Hucheng's army who had given significant aid to Liu Zhidan's guerrillas, approached Xu's army as it passed through south Shaanxi. Xu interrogated the contact, doubted his credentials, and had him shot. ${ }^{187}$ It was a telling sign of Xu's suspicious attitude toward the Shaanxi party's judgment.

In September 1935, Xu Haidong's army arrived at the new Red headquarters in the town of Yongping, northeast of Yan'an. Xu's Twenty-Fifth Army was not large, probably only about two thousand men, but they were well armed and battle tested. ${ }^{188}$ The recollection of one of their political officers indicates that the initial meeting with Liu Zhidan's forces did not go well.

The Twenty-Fifth Army had reached Shaanbei in victory. Everyone thought we were great: number one in the country. This arrogance increased after we joined with the Twenty-Sixth and Twenty-Seventh Armies. The Twenty-Fifth was well armed: many machine guns and good rifles. We had good uniforms. Because we had come from 
the white areas, had attacked the local strongmen, our clothing was quite elegant. We had eaten well; everyone was healthy and fat. We had plenty of ammunition. When we met our brother armies, the Twenty-Sixth and Twenty-Seventh, we thought: "What kind of army is this?" We looked down on them: only a few bullets and wearing all kind of clothes. They not only lacked good boots, they had no socks, no uniforms, and they tied a white cloth around their heads. ${ }^{189}$

Needless to say, the southern forces were uninterested in advice from the local Communists. In Yongping, Xu Haidong wanted to hear from Guo Hongtao and Zhu Lizhi, the representatives of the Center. Their criticism of Liu's Twenty-Sixth Army was critical in a series of September meetings that reorganized the entire structure of the revolutionary movement in Shaanbei. ${ }^{190}$

The Northwest Work Committee that Zhu Lizhi headed was replaced by a new CCP Shaanxi-Gansu-Shanxi provincial committee (中共陕甘晋省委) with Zhu Lizhi as secretary and Guo Hongtao as his deputy. The military committee of this new province was headed by Nie Hongjun, the other representative sent from Shanghai. Finally, the three armies of Liu, Xu, and the late Xie Zichang were reorganized into the Fifteenth Army Group commanded by Xu Haidong, with Cheng Zihua from Xu's army serving as political commissar. ${ }^{191}$ The local troops were not happy with their new leaders. Given the arrogance of the southern troops, and the fact that they were speaking a strange southern dialect, this is unsurprising. More important was the fact that the Shaanbei troops were accustomed to close relations between officers and men, with soldiers' committees to discuss operations and leaders like Liu Zhidan known simply as "Old Liu." Now they were confronted with a Red Army that looked and acted more like the enemy they had been fighting. They were particularly offended to see officers cursing and beating ordinary soldiers. ${ }^{192}$ The final step in the subordination of the Shaanbei forces came when Zhu Lizhi ordered the Twenty-Sixth Army to turn over its recently captured and much-prized machine guns to Xu Haidong's army. ${ }^{193}$ With the support of Xu Haidong's army from Hubei, Zhu Lizhi and Guo Hongtao had completely sidelined Liu Zhidan and were now prepared to launch a purge of "opportunist" elements in his movement.

The campaign against Liu Zhidan's unorthodox methods was long-standing. The Bolsheviks in the provincial committee had repeatedly criticized his recruitment of bandits, his preference for guerrilla warfare along the Shaan-Gan border, and his failure to carry out land reform. Critical reports from Xian had long circulated in Shanghai and had certainly been passed on to the North China bureau. When Guo Hongtao, followed by Zhu Lizhi, was sent to rectify the Shaanbei party, he was based in the northeast of the province, where negative reports on the Shaan-Gan guerrillas were reinforced by criticisms from Xie Zichang and the more orthodox "Shaanbei" party. Most of these reports were familiar criticisms of Liu's use of associates in the Society of Brothers, the militia, and even the Nationalist Party to build the revolutionary movement. ${ }^{194}$ From 1934, however, a new charge 
was added. Liu was alleged to be working with agents of Zhang Mutao. Zhang was a former head of the Shaanxi youth league who had quarreled with the provincial committee in 1928, then moved on to underground party work in North China, including anti-Japanese organizing in Chahar. There he had again fallen out with his comrades, had been expelled, and while working in Shanxi had formed a rival "New Communist Party." By 1935 Zhang was back in Xi'an. With the provincial apparatus in shambles, he seems to have worked with other leftists, progressive members of Yang Hucheng's entourage, and disaffected members of the Communist Party. While the activities of Zhang Mutao's rival group remain obscure, the Center's representatives were concerned, and rumors that Liu Zhidan was working with this new group of patriotic leftists provoked particular suspicion. Since Zhang Mutao was an independent leftist, operating outside the orthodox party apparatus, he was predictably (though inaccurately) labeled a "Trotskyite." 195 Liu Zhidan, for his part, had lost contact with the party Center in 1933 and was seeking a variety of plausible agents to reestablish connections and build a broad revolutionary movement in Shaanbei. Liu had never been an ideological thinker and was always willing to work with a diverse mix of allies with questionable histories. Zhang Mutao and his colleagues were among the people Liu's men contacted. Liu's preference for a broad united front would get him in trouble again.

First, however, there were military matters to attend to. In this case, Xu Haidong and Liu Zhidan were on the same page. Some of the party representatives wanted to attack north toward the Shenmu base-perhaps as preparation for opening a road to the Soviet border through Inner Mongolia-but Xu and Liu realized that the immediate threat came from the large Northeast Army of Zhang Xueliang, which had already occupied Yan'an and needed to keep a supply line open from Xian. ${ }^{196}$ In the critical Laoshan battle that ensued, Xu Haidong was technically in command, but he seems to have deferred to Liu's superior knowledge of the local topography. The road to Yan'an passed through Ganquan, so that town was first isolated and besieged. To relieve the siege and reopen the road, a relief column had to come from Yan'an. There was an obvious ambush site, but Liu correctly assumed that the enemy would prepare for an attack there. He chose the Laoshan site further south. As anticipated, the Northeast Army column relaxed after passing the first site, decided to press on to Ganquan, and was attacked. A fierce battle lasting six hours ensued in which the Nationalists lost a divisional commander, hundreds of casualties, and at least three or four hundred captured. The Communists also gained hundreds of new weapons and a large cache of ammunition. ${ }^{197}$ This was a major defeat for Zhang Xueliang's forces. In the short term, it led to the abandonment of Wayaobu and in the longer run to Zhang's serious doubts about the wisdom, both politically and militarily, of continuing to fight the Communists rather than the Japanese occupying his homeland. ${ }^{198}$

The Laoshan battle was Liu Zhidan's final military victory, and much laudatory prose has described his tactical brilliance. But there was another side of the story. Though Liu may have been responsible for the tactical details, Xu Haidong was 
in command, and he arrayed his own forces on the flanks and rear, leaving Liu responsible for the central assault. The battle lasted much longer than planned and certainly longer than the brief ambushes by Liu's army in the past, and some of Liu's officers felt that Xu was deliberately sacrificing the Shaanbei armies-a credible complaint given the arrangement of the forces and the disdain in which he held the Shaanbei armies. As a result, Liu's army suffered significant losses: seven of twelve company commanders were killed, and only two hundred men emerged unscathed from one regiment of seven hundred. ${ }^{199}$ The Guomindang press falsely reported that Liu himself had been killed. ${ }^{200}$ The situation was made worse when Xu Haidong threatened to execute an officer whom he deemed insufficiently aggressive. Opposition from the ranks halted this move, but the damage had been done, and there were defections and even suicides among the Shaanbei troops. After the battle, Xu's Twenty-Fifth Army got the best of the captured rifles, and the Shaanbei troops were sent to a desolate area with no food where they were ordered to attack a well-fortified enemy position, which only enhanced their discontent. ${ }^{201}$ Little did they realize that the worst was yet to come. Immediately after the Laoshan battle, Liu Zhidan was summoned to Wayaobu and thrown into jail. When the arrest warrant was mistakenly delivered to Liu himself, he read it and then, obedient as always, proceeded to Wayaobu to turn himself in. ${ }^{202}$ Many of his officers were reassigned or arrested. Others were threatened, then sent into poorly prepared battles, with heavy losses, much grumbling, and some departures. ${ }^{203}$ Throughout Shaanbei, a campaign against “counter-revolutionaries" (sufan 肃反) was spreading out of control.

\section{REVOLUTION AND COUNTER-REVOLUTION}

The sufan campaign in the late summer and fall of 1935 was a wholesale attack on Liu's Shaan-Gan soviet. All of his key lieutenants were arrested: Gao Gang, Liu's brother Jingfan, the Red Army officer Zhang Xiushan, and Xi Zhongxun, head of the Shaan-Gan soviet and father of China's current president and party secretary $\mathrm{Xi}$ Jinping. In all, over one hundred officers and cadres were arrested, with the key leaders imprisoned, shackled, and held in cold, dark, lice-infected caves in Wayaobu with only straw to sleep on. ${ }^{204}$ The Center's representatives, Zhu Lizhi and Guo Hongtao, had laid the groundwork with their attacks on the "right opportunism" of the Shaan-Gan revolutionaries. The execution of the sufan campaign was in the hands of the Twenty-Fifth Army operatives. In Wayaobu, the interrogations were led by Dai Jiying, political officer of the Twenty-Fifth Army and leader of the violent sufan in the Hubei-Henan-Anhui Soviet. His methods were direct and crude: "Dai Jiying was a cruel god; he loved to beat people. He cursed you in his Hubei dialect: 'Motherfucker!' Carrying a big club, he'd start cursing and beating as soon as he entered the door." ${ }^{205}$ One of Dai's first victims was Liu's lieutenant Zhang Xiushan. After repeated torture, Zhang was convinced that his persecutors were themselves enemies of the revolution and that his only option 
was confession and death. He apparently implicated Liu Zhidan, but once the torture stopped, he recanted. As this pattern was repeated again and again, even Zhu and Guo began to doubt the forced confessions and demanded to witness the interrogations, but they did nothing to stop the purge. ${ }^{206}$ This was the crudest form of factional struggle. None of the key lieutenants of the late Xie Zichang were affected. ${ }^{207}$ In the end, most of the confessions of the imprisoned leaders were rejected as false testimony extracted under torture. ${ }^{208}$ At the time, however, the threat was real: outside their caves, the prisoners heard workers digging a great pit and were told it would be their mass grave. ${ }^{209}$

As the Shaan-Gan leaders were arrested and imprisoned in Wayaobu, the purge spread to their subordinates and local cadres in the Shaan-Gan soviet. All cadres at the county level and above and all military officers at the battalion level and above were targeted. ${ }^{210}$ The agents of this purge were security officials from Xu Haidong's Twenty-Fifth Army, and the level of violence intensified. Memoirs speak of young armed men in black uniforms speaking southern accents, who came to seize, torture, and often execute local Communist officials. ${ }^{211}$ Sometimes they were able to find local allies, people with personal grievances or common thugs. Mass meetings were called, and if there were complaints against local cadres, they were promptly executed. There are numerous reports of people being buried alive in the purge. ${ }^{212}$ In all, according to the official verdict, two hundred perished in the campaign against alleged "counter-revolutionaries."213

With enemy forces encircling the newly formed soviets and the Red Army outnumbered ten to one, it is difficult to fathom why the Communists would have turned on their own comrades in an orgy of internecine carnage, but this was hardly an isolated incident in the history of the Chinese Revolution. In the Futian incident in 1930, allies of Mao Zedong executed several thousand dissidents on suspicion of disloyalty. ${ }^{214}$ More directly relevant was the "genocidal Party purge" in the Hubei-Henan-Anhui Soviet that cost the lives of thousands of local cadres. ${ }^{215}$ The executors of the Shaanbei campaign were precisely the men who had directed the purge in Hubei, and it was their model. ${ }^{216}$ The precarious state of the revolutionary forces did not prevent them from turning on their own. On the contrary, it seemed to enhance the fear of spies, disloyal elements, or those who harbored doubts and might waver in the face of the enemy. In most cases, it was agents of the party Center who harbored such fears, and local revolutionaries who were the victims. That was precisely the case in Shaan-Gan, where the purge was launched by Zhu Lizhi and the representatives of the party Center, and carried out by Xu Haidong's army from Hubei.

Local considerations inevitably influenced the progress of the purge. In the background, there was always the simmering conflict between the "Shaanbei" and Shaan-Gan factions. The "Shaanbei" party communicated with Beijing and resented the Shaan-Gan faction's connections to the provincial committee in Xian. ${ }^{217}$ This made them suspicious of any influence coming from the provincial capital. Liu Zhidan, however, was desperately trying to reestablish the Xian link 
after the arrests and collapse of the provincial committee in 1933. His contacts with CCP agents in Yang Hucheng's army naturally aroused the suspicions of the "Shaanbei" faction, which passed them on to Zhu Lizhi and the other representatives of the Center. As a result, the view spread that "everyone from Xian is problematic." 218 In fact, the Shaan-Gan revolutionaries had long recruited workers and students from Xi'an and other Wei River towns, but now these students and intellectuals came under suspicion. ${ }^{219}$ Zhang Mutao, the expelled Communist who had formed a "New Communist Party," was a particular object of suspicion, and Liu Zhidan's efforts to reach the Xi'an party had brought him into contact with Zhang Mutao's associates. One of these was Huang Ziwen, the Sanyuan leader and open critic of Wang Ming and the young leaders who dominated the Central Committee after 1931. Huang had joined the Shaan-Gan guerrillas, and while Liu treated him with some suspicion, the presence of such "right opportunists" in Liu's entourage was unacceptable to the sufan leaders. ${ }^{220}$

Whenever a leftist tide brought new attention to class status and purifying the party of class enemies, intellectuals inevitably bore the brunt of the attack. Most came from families of some means, and their superior education created a social distance from the general population. In normal times, that could earn them respect, and the party certainly grew in part because respected teachers spread its message. But when class lines came to the fore, intellectuals were likely to suffer. Among cadres, the better educated were often targeted. ${ }^{221}$ In the Shaan-Gan sufan, this took on an important gendered dimension. Many of the women who joined the revolution were students from urban schools. They seem to have come under particular suspicion in the sufan campaign, and a significant number of those killed were young women. ${ }^{222}$ But there were also local women whose reputations for loose sexual behavior brought them under suspicion. Indeed, a widespread purge such as this targeted a broad range of unconventional social types. According to Guo Hongtao, his team killed beggars as suspected spies, "and because we leaders acted in this manner, lower levels followed along, killing bandits, hooligans, prostitutes, yamen runners, and beggars." 223 The killings usually happened at night, secretly and without trials. ${ }^{224}$

The fear of enemy agents and the influence of alien class elements may have provided the pretext for a violent purge. But the ideological deviation that the party aimed to correct was Liu Zhidan's inattention to class status in building his movement and in land reform. Liu was a military man and began his career in the warlord armies of Feng Yuxiang and Ma Hongkui, then took positions under lesser warlords in Gansu, using his status as an officer to lead mutinies. This strategy was quite common during and immediately after the united front with the Nationalists in the 1920s. It was exactly the approach taken by Zhu De in founding the Red Army in Jiangxi. By the 1930s, however, as a left line dominated the party Center, underground work in Nationalist and warlord armies was supposed to target ordinary soldiers, arousing them to revolt against abusive officers. Liu, however, saw the impracticality of this approach and continued to seek out officers 
with whom he could work. He was also willing to use his connections in the Society of Brothers to approach local militia commanders. He even used a sympathetic Guomindang security chief in his soviet regime. ${ }^{225}$ In all these efforts, he especially appealed to the rising anti-Japanese movement in the press, among students and intellectuals, and in the military. He was carrying out a united front policy before it was officially authorized by the party Center.

In the course of the sufan campaign, all of these efforts aroused suspicion. In 1945, Zhu Lizhi offered a plausible summary of his conflict with Liu:

\begin{abstract}
At the time, Liu Zhidan and I had significant differences on the correct line. As a result, we had many fights. . . . In land reform, they only confiscated the rich peasant land under feudal exploitation [i.e., rented land], proposed uniting with rich peasants, and treated large and small landlords differently. We, however, proposed giving rich peasants only poor land and physically eliminating landlords, even expelling all army officers and soldiers with landlord and rich peasant backgrounds. In the White [Nationalist] army, Liu Zhidan and the others wanted to win over both officers and soldiers. We cursed their efforts to form a united front with Yang Hucheng or Sun Dianying as "conspiring with army officers." They adopted a policy of winning over bandits and members of the Society of Brothers; we cursed them for following a "bandit policy." Toward intellectuals from outside the soviets, they adopted a trusting posture; we said they were "ignoring the leadership of the proletariat." 226
\end{abstract}

In Zhu's account, class consciousness was the key link in all the policy differences. It was Liu's lack of a proper class consciousness that led him to conspire with Nationalist army officers, attract intellectuals with questionable backgrounds, recruit militia members from landlord families, and favor rich peasants in his land reform policies. Now the sufan campaign would correct these errors.

Naturally the campaign began by attacking Liu Zhidan himself. Because his family had land and a position in the militia, it was classified as a "bureaucratic landlord family." Many of the local militia leaders whom Liu had persuaded to join his movement were from similar families. ${ }^{227}$ When the Shaan-Gan soviet, under pressure from the party, carried out land reform in 1934-35, it had been quite moderate. Land was plentiful, and one wartime document claimed that "most people were rich or middle peasants; poor peasants were few." ${ }^{228}$ With no demand for unirrigated hill land, it was unaffected by land reform. Only rented valley land was redistributed, and landlords were allowed to keep enough to support themselves. All of this was sheer opportunism in the eyes of the sufan agents from Hubei and the Center. They launched a “land investigation" (chatian 查田) movement to correct past errors, calling for a "cruel class struggle against gentry strongmen, landlords, and rich peasants." 229 Hubei cadres were incredulous when ordinary peasants reported that they owned "several mountains" of land, and arbitrarily decided that anyone with over one hundred $m u$ (about sixteen acres) was a landlord. ${ }^{230}$ Such landlords had all their land confiscated; they were driven from their homes and sent to work for the government or to the hills to "eat grass." ${ }^{31}$ In one particularly 
ill-conceived policy, landlords' sheep were redistributed to agricultural laborers who were unwilling or unable to care for them, so they roamed free in the hills to be eaten by wolves. ${ }^{232}$

We should not assume that there was no local support for the radical "land investigation" campaign. Along the Shaan-Gan border, land was not equally distributed. In Baoan, almost all the land was owned by the old residents (laohu 老户) of the county, descendants of families that had survived the nineteenthcentury Muslim Rebellion, while perhaps 90 percent of the population were migrants from the densely populated, famine-stricken counties further east. ${ }^{233}$ While most of these migrants found land to rent or worked for the old families, the land investigation teams were probably able to locate and mobilize some disaffected migrants who wanted land of their own. ${ }^{234}$ In this sense, the memoirs and local informants who uniformly support the official narrative of popular opposition to radical land reform must be treated with a degree of skepticism. Nonetheless, it is clear that the arrest of Liu Zhidan, the execution of local cadres, and then a radical land reform imposed from the outside were not popular.

The reaction began soon after the purge was launched in September 1935. We have already seen the resentment toward Xu Haidong's Hubei troops and Liu's soldiers' reactions to losses during the Laoshan and later battles. Local soldiers began to sleep with their weapons at the ready, and some deserted at night. ${ }^{235}$ In the southern areas, close to Guanzhong, the purge was particularly intense, and many peasants fled the soviet zone as rumors spread that Xu Haidong had killed Liu Zhidan. ${ }^{236}$ The most serious reaction began in Liu Zhidan's home county of Bao'an. The precipitating factor was the arrest and execution of a number of former militia leaders, all from landlord families or former students in Yulin. They had been recruited to the revolutionary camp by Liu Zhidan and his allies, then summoned by the sufan leaders and executed-buried alive. In November, another arrest warrant fell into the hands of its intended target, a militia leader in northern Baoan. He led his men to turn against the revolution, held a mass meeting in early December, then joined one of the few Luo River militia leaders who had resisted the revolution from his well-protected mountain-top fortress. Soon, seven or eight guerrilla units with militia or Society of Brothers connections also defected, and six of the ten soviet districts near Liu's home on the Luo River turned against the revolution. When Liu Jingfan returned in the winter, only 150 of 1,000 party members remained. ${ }^{237}$

In other areas, when local cadres were arrested, party organizations were paralyzed. ${ }^{238}$ According to one Guomindang report, the soviet governments in four northwest Shaanxi counties were toppled. ${ }^{239}$ The response to the radical sufan campaign was not surprising. Liu Zhidan unquestionably had a substantial following as a local leader opposing oppressive taxation and warlord depredations. Above all, he was a Shaanbei native, from a respected family, and well connected to the powerful Brother networks. Now he had been removed and his nascent regime decapitated by an unknown group of outsiders speaking a strange southern dialect. The Shaanbei revolution was in crisis. 
At this critical moment, in mid-October 1935, Mao Zedong and the Central Red Army arrived on the western border of the Shaanbei soviet. Informed by the local authorities of the spreading purge, he issued a legendary order: "Halt the executions! Stop the arrests." ${ }^{240}$ Such, at least, is the official account. There are, however, reasons for skepticism. The sufan campaign led to widespread suspicion of unknown armies from the south. After the Laoshan battle, some claimed that "the Twenty-Fifth Army is a White [Guomindang] Army disguised as a Red Army to eliminate the Twenty-Sixth Army." ${ }^{411}$ When Mao's troops arrived in the small town of Wuqi in the western part of Baoan, the residents hid in the hills before local cadres convinced them to greet this new army in straw sandals and tattered clothes, which also claimed to be part of the Red Army. ${ }^{242}$ Over the next month and a half, as arrests and executions continued, Mao and the party Center passed through the headquarters of the local soviet, received a report from the architects of the purge, and met with Xu Haidong. Only in late November or early December, when Zhou Enlai and representatives of the central leadership arrived in Wayaobu, was the order given to release Liu Zhidan, Gao Gang, Xi Zhongxun, and the other arrested leaders. ${ }^{243}$ Though Mao at some point certainly judged the executions to be excessive, his sympathies were decidedly with Xu Haidong's more class-conscious policies, and not with the sort of militia leaders and Society of Brothers members that Liu Zhidan had attracted to his revolution.

A committee was established to investigate the sufan campaign, and it rendered a mixed verdict. The sufan campaign was deemed necessary but excessive. Zhang Mutao's "counter-revolutionary group" was alleged to have infiltrated the ShaanGan soviet, and its "right capitulationism" was identified as a grave threat to the revolution. The campaign's excesses were attributed to Dai Jiying of the TwentyFifth Army, while the key representatives of the Shanghai Center, Zhu Lizhi and Guo Hongtao, survived unscathed. Indeed, their power was enhanced: the Shaanxi-Gansu-Shanxi "province" was abolished and replaced by Shaanbei Province, with Guo Hongtao as secretary, and Shaan-Gan Province, with Zhu Lizhi as secretary. There they continued to discriminate in appointments against members of the Shaan-Gan faction, which was accused of conciliation, liberalism, and localism. ${ }^{244}$ Liu Zhidan, for his part, was left in limbo, accused in his dossier of "extreme rightist tendencies." ${ }^{245} \mathrm{He}$ was returned to the army, but in a subordinate position. The Twenty-Eighth Army that he now commanded was not his old army but a new unit, much smaller, that would serve him poorly in the year to come. ${ }^{246}$

In a brief flash of glory, Liu Zhidan's time had come and gone. He was free again, but the Shaanbei revolution was no longer his to shape. There was a new sheriff in town. 